Article

\title{
Enteropathogenic Potential of Bacillus thuringiensis Isolates from Soil, Animals, Food and Biopesticides
}

\author{
Valerie Schwenk ${ }^{1}$, Janina Riegg ${ }^{1}$, Monique Lacroix ${ }^{2}$, Erwin Märtlbauer ${ }^{1}$ \\ and Nadja Jessberger ${ }^{1, *}$ \\ 1 Department of Veterinary Sciences, Faculty of Veterinary Medicine, Ludwig-Maximilians-Universität \\ München, Schönleutnerstr. 8, 85764 Oberschleißheim, Germany; \\ Valerie.Schwenk@mh.vetmed.uni-muenchen.de (V.S.); janina.riegg@gmx.net (J.R.); \\ e.maertlbauer@mh.vetmed.uni-muenchen.de (E.M.) \\ 2 Centre Armand-Frappier Santé Biotechnologie, 531, boul. des Prairies, Laval, QC H7V 1B7, Canada; \\ Monique.Lacroix@iaf.inrs.ca \\ * Correspondence: N.Jessberger@mh.vetmed.uni-muenchen.de
}

Received: 23 September 2020; Accepted: 15 October 2020; Published: 17 October 2020

check for updates

\begin{abstract}
Despite its benefits as biological insecticide, Bacillus thuringiensis bears enterotoxins, which can be responsible for a diarrhoeal type of food poisoning. Thus, all 24 isolates from foodstuffs, animals, soil and commercially used biopesticides tested in this study showed the genetic prerequisites necessary to provoke the disease. Moreover, though highly strain-specific, various isolates were able to germinate and also to actively move, which are further requirements for the onset of the disease. Most importantly, all isolates could grow under simulated intestinal conditions and produce significant amounts of enterotoxins. Cytotoxicity assays classified 14 isolates as highly, eight as medium and only two as low toxic. Additionally, growth inhibition by essential oils (EOs) was investigated as preventive measure against putatively enteropathogenic $B$. thuringiensis. Cinnamon Chinese cassia showed the highest antimicrobial activity, followed by citral, oregano and winter savory. In all tests, high strain-specific variations appeared and must be taken into account when evaluating the hazardous potential of $B$. thuringiensis and using EOs as antimicrobials. Altogether, the present study shows a non-negligible pathogenic potential of $B$. thuringiensis, independently from the origin of isolation. Generally, biopesticide strains were indistinguishable from other isolates. Thus, the use of these pesticides might indeed increase the risk for consumers' health. Until complete information about the safety of the applied strains and formulations is available, consumers or manufacturers might benefit from the antimicrobial activity of EOs to reduce the level of contamination.
\end{abstract}

Keywords: Bacillus thuringiensis; Bacillus cereus; food infections; enterotoxins; cytotoxicity; essential oils; risk evaluation; biopesticide

\section{Introduction}

Bacillus thuringiensis is a Gram-positive and spore-forming bacterium, which is used worldwide as biopesticide due to its capability to produce insecticidal proteins [1-3]. The two main parasporal toxins are Cyt (cytolytic) and Cry (crystal) toxins [4]. In addition to that, B. thuringiensis produces other entomopathogenic factors such as vegetative insecticidal proteins (Vip) and secreted insecticidal proteins (Sip) $[1,5,6]$. As a result of its distinct types of toxins, B. thuringiensis is virulent to a wide range of insect orders and species, e.g., Coleoptera, Diptera and Lepidoptera, as well as nematodes and even plant and animal pathogenic microorganisms $[2,7,8]$. A clear advantage is the host-specific mode of action of the mentioned toxins, which do rarely harm non-target species. 
Despite the benefits, the close relation to other members of the Bacillus cereus group must not be neglected. The B. cereus group includes at least eight species: B. cereus sensu stricto, B. anthracis, B. weihenstephanensis, B. mycoides, B. pseudomycoides, B. cytotoxicus, B. toyonensis and B. thuringiensis [9-12], while recently, more and more additional species are described. B. cereus s. s. is a human pathogen that causes two types of foodborne diseases, the emetic syndrome due to cereulide intoxication and the diarrhoeal type of disease [12]. The latter arises from an infection with vegetative cells, which produce enterotoxins, mainly the non-haemolytic enterotoxin (Nhe), haemolysin BL ( $\mathrm{Hbl})$ and cytotoxin $\mathrm{K}$ (CytK), in the human intestine [13-17]. Like B. cereus, B. thuringiensis exhibits the enterotoxin genes nhe, $h b l$ and $c y t K$ [18-20]. Moreover, $B$. thuringiensis could be related to food-borne outbreaks [21]. These facts led to the debate if the biopesticides represent a risk for public health and thus, it seems questionable using potential harmful preparations extensively in agriculture. A further problem is that routine clinical and food diagnostics does not usually differentiate the $B$. cereus group species $[22,23]$. Thus, food-borne diseases and clinical infections caused by $B$. thuringiensis might be significantly under-reported. The aim of this study was to investigate the toxic and enteropathogenic potential of B. thuringiensis isolates gained from food, animal and soil samples, as well as from commercially used biopesticides. These 24 isolates were systematically characterized regarding their phylogenetic relationship, occurrence of toxin genes, growth and enterotoxin production under simulated intestinal conditions, cytotoxic activity, as well as further pathogenicity factors involved in the onset of B. cereus-associated food infections, such as spore germination and motility. Moreover, growth inhibition by essential oils (EOs) was investigated as preventive measure against putatively enteropathogenic $B$. thuringiensis.

\section{Materials and Methods}

\subsection{Bacterial Strains and Culture Conditions}

The B. thuringiensis strains used in this study are listed in Table 1 . For gaining cell-free culture supernatants, they were pre-cultured in casein glucose yeast (CGY) medium with $1 \%$ glucose for $17 \mathrm{~h}$ at $32{ }^{\circ} \mathrm{C}$ and $200 \mathrm{rpm}$. Samples of $20 \mathrm{~mL}$ fresh CGY medium were inoculated to an optical density $\left(\mathrm{OD}_{600}\right)=0.2$ and cultured for further $6 \mathrm{~h}$. After centrifugation at $3500 \mathrm{rpm}$ and $4{ }^{\circ} \mathrm{C}$ for $12 \mathrm{~min}$, $1 \mathrm{mM}$ ethylenediaminetetraacetic acid (EDTA) was added, the supernatants were filtered through a $0.2 \mu \mathrm{m}$ filter, aliquoted and stored at $-20^{\circ} \mathrm{C}$. For cultivation under simulated intestinal conditions, preparation of "conditioned" (cRPMI) medium was carried out as described previously [15]. In brief, RPMI 1640 medium (with stable glutamine; Biochrom AG, Berlin, Germany), supplemented with 1\% glucose and $2 \%$ casein hydrolysate, was incubated with differentiated $\mathrm{CaCo}-2$ cells for $22 \mathrm{~h}$ and filtered using a $0.2 \mu \mathrm{m}$ filter. Overnight cultures obtained as described above were incubated at $37^{\circ} \mathrm{C}$ and adjusted to a start $\mathrm{OD}_{600}$ of $0.05 \mathrm{in} 20 \mathrm{~mL}$ cRPMI. They were incubated statically at $37^{\circ} \mathrm{C}$ and $7 \% \mathrm{CO}_{2}$ atmosphere. For growth analyses, $\mathrm{OD}_{600}$ was measured every hour for eight hours. Cell-free culture supernatants were harvested after six hours as described above. 
Table 1. Overview of the 24 B. thuringiensis strains used in this study. Origin of the isolates: A: animal, F: food, P: pesticide, S: soil, U: undefined. +: positive PCR result for toxin gene. -: negative PCR result for toxin gene. *: NheB production determined in sandwich enzyme immunoassays (EIAs) after growth under simulated intestinal conditions according to Jessberger et al. [15]. **: Cytotoxicity towards CaCo-2 cells after growth under simulated intestinal conditions according to Jessberger et al. [15].

\begin{tabular}{|c|c|c|c|c|c|c|c|c|c|c|c|c|}
\hline $\begin{array}{c}\text { Internal } \\
\text { Number (MHI) }\end{array}$ & Other Designation & Source & Origin & panC Type & cry & nhe & $h b l$ & ces & cytK1 & cytK2 & NheB * & Toxicity ** \\
\hline 271 & B. thuringiensis Berliner 1915, DSM 6029 & Animal tissue & A & IV & 1 & + & + & - & - & + & High & High \\
\hline 2873 & $\begin{array}{l}\text { B. thuringiensis Berliner 1915, ATCC }{ }^{\circledR} \\
\text { 10792 }^{\mathrm{TM}}, \text { DSM } 2046\end{array}$ & Mediterranean flour moth & A & IV & 1 & + & + & - & - & + & High & High \\
\hline 2882 & $\begin{array}{l}\text { B. thuringiensis ssp. israelensis, BGSC 4Q2 } \\
\text { (HD500) }\end{array}$ & Culicidae larva & A & IV & 4 & + & + & - & - & + & High & Medium \\
\hline 3370 & B. thuringiensis Bt 407 & $\begin{array}{l}\text { Ephestia kuehniella larva; } \\
\text { Cry- }\end{array}$ & A & IV & - & + & + & - & - & + & High & High \\
\hline 2880 & B. thuringiensis WSBC 28025 & Vegetables for infant food & $\mathrm{F}$ & IV & 1,2 & + & + & - & - & + & Medium & High \\
\hline 3163 & B. thuringiensis & Ready-to-eat salad 1 & $\mathrm{~F}$ & IV & 1,2 & + & + & - & - & + & High & High \\
\hline 3164 & B. thuringiensis & Ready-to-eat salad 2 & $\mathrm{~F}$ & IV & 1,2 & + & + & - & - & + & Medium & High \\
\hline 3189 & B. thuringiensis & Ready-to-eat salad 3 & $\mathrm{~F}$ & IV & 1,2 & + & + & - & - & + & Low & Medium \\
\hline 3190 & B. thuringensis & Ready-to-eat salad 4 & $\mathrm{~F}$ & IV & 1,2 & + & + & - & - & + & Low & Medium \\
\hline 3191 & B. thuringiensis & Ready-to-eat salad 5 & $\mathrm{~F}$ & IV & 1 & + & + & - & - & + & Low & High \\
\hline 2878 & B. thuringiensis ssp. tenebrionis & Undefined biopesticide & $\mathrm{P}$ & IV & 3 & + & + & - & - & - & Low & Medium \\
\hline 3186 & B. thuringiensis ssp. aizawai & Biopesticide granulate 1 & $\mathrm{P}$ & IV & 1,2 & + & + & - & - & + & Low & High \\
\hline 3187 & B. thuringiensis ssp. aizawai & Biopesticide granulate 1 & $\mathrm{P}$ & IV & 1,2 & + & + & - & - & + & Low & Medium \\
\hline 3188 & B. thuringensis & Isolate from Biopesticide 1 & $\mathrm{P}$ & IV & 1,2 & + & + & - & - & + & Low & High \\
\hline 3240 & B. thuringensis ssp. kurstaki & Biopesticide 2 & $\mathrm{P}$ & IV & 1,2 & + & + & - & - & + & Medium & High \\
\hline 3241 & B. thuringiensis ssp. tenebrionis & Biopesticide 3, solids & $\mathrm{P}$ & IV & 3 & + & + & - & - & - & Medium & Low \\
\hline 3369 & B. thuringiensis ssp. aizawai & Biopesticide 4 & $\mathrm{P}$ & IV & 1,2 & + & + & - & - & + & Low & High \\
\hline 2874 & B. thuringiensis ssp. kurstaki, PO1 & Soil & $\mathrm{s}$ & IV & 1 & + & + & - & - & + & High & Medium \\
\hline 2875 & B. thuringiensis ssp. kurstaki, $\mathrm{PO} 6$ & Soil & $\mathrm{s}$ & IV & 1 & + & + & - & - & + & High & High \\
\hline 2876 & B. thuringiensis ssp. kurstaki, $\mathrm{PO} 10$ & Soil & $\mathrm{s}$ & IV & 1 & + & + & - & - & + & Medium & High \\
\hline 2877 & B. thuringiensis ssp. kurstaki, $\mathrm{PO} 14$ & Soil & S & IV & 1 & + & + & - & - & + & High & High \\
\hline 2870 & $\begin{array}{l}\text { B. thuringiensis ssp. entomocidus bv. } \\
\text { subtoxicus, IEBC-T06A001 }\end{array}$ & Canada & U & IV & 1,2 & + & + & - & - & + & Medium & Low \\
\hline 2871 & B. thuringiensis & Undefined & U & IV & 1,2 & + & + & - & - & + & Medium & Medium \\
\hline 2872 & B. thuringiensis HER 1404 & Undefined & U & IV & 1,2 & + & + & - & - & + & Medium & Medium \\
\hline
\end{tabular}




\subsection{Cell Lines and Culture Conditions}

CaCo-2 cells from DSMZ (German Collection of Microorganisms and Cell Cultures, Braunschweig, Lower Saxony, Germany) were cultivated in RPMI 1640 medium (with stable glutamine) supplemented with 10\% foetal bovine serum (Biochrom AG, Berlin, Germany). For cultivation, $80 \mathrm{~cm}^{2}$ culture flasks and a humidified incubator $\left(37^{\circ} \mathrm{C}\right.$ and $\left.7 \% \mathrm{CO}_{2}\right)$ were used. Cells were passaged 1:6 every three to four days. For differentiation, cells were incubated for 14 days. Medium was changed every three to four days.

\subsection{PCR Analyses}

Generally, amplification was performed with a total volume of $50 \mu \mathrm{L}$ in a Biometra thermocylcer (Analytik Jena, Jena, Thuringia, Germany). The reaction mixtures contained $5 \mu \mathrm{L} 10 \times$ buffer, $4 \mu \mathrm{L}$ $\mathrm{MgCl}_{2}(25 \mathrm{mM}), 1 \mu \mathrm{L}$ dNTP suspension (10 mM each), $0.5 \mu \mathrm{L}$ Taq DNA polymerase, $2.5 \mu \mathrm{L}$ of each primer $(10 \mu \mathrm{M})$ and $2 \mu \mathrm{L}$ template DNA (colony material). Initial denaturation at $95{ }^{\circ} \mathrm{C}$ for five minutes was followed by 30 reaction cycles: denaturation at $95^{\circ} \mathrm{C}$ for $15-60 \mathrm{~s}$, annealing for $15-60 \mathrm{~s}$ at the appropriate temperature (see Table S1) and extension for $20-60 \mathrm{~s}$ at $72{ }^{\circ} \mathrm{C}$. The final extension was performed at $72{ }^{\circ} \mathrm{C}$ for seven minutes. PCR fragments were separated on $1 \%$ agarose gels by electrophoresis and made visible by UV illumination. Primers used for all PCR analyses are listed in Table S1. First, the panC (pantothenate synthetase) gene was amplified for sequence analysis (see Section 2.4). Subsequently, all strains were screened for cry toxin genes and allocated to five groups according to Ben-Dov et al. [24]. Furthermore, the strain set was tested for the presence of the (entero)toxin genes $h b l C$, nhe A, ces and cytK1 via multiplex PCR according to Wehrle et al. [25], as well as cytK2 according to Ehling-Schulz et al. [26].

\subsection{PanC Sequence Typing}

To allocate the $B$. thuringiensis isolates tested in this study to phylogenetic groups, sequencing of a $485 \mathrm{bp}$ fragment of the pantothenate synthetase gene (panC; [27]) was applied (Eurofins Genomics Germany GmbH, Ebersberg, Bavaria, Germany). Sequences were aligned using CLUSTAL $\Omega$ [28]. Further cluster analysis was carried out using SplitsTree software (version 4, Eberhard Karls University Tübingen, Tübingen, Baden-Württemberg, Germany ) [29]. The sequences of the following reference strains were added to the analysis: type I: B. pseudomycoides 219,298 (CP007626.1); type II: B. wiedmannii SR52 (CP032365.1); type III: B. anthracis Ames (AE016879.1); type IV: B. cereus ATCC 14579 (NC_004722.1); type V: B. toyonensis BCT-7112 (CP006863.1); type VI: B. weihenstephanensis WSBC 10,204 (DQ301426.1); type VII: B. cytotoxicus NVH391-98 (CP000764.1) [23,27,30].

\subsection{Spore Preparation}

B. thuringiensis spores were prepared as described previously [14,31,32]. Briefly, $100 \mathrm{~mL}$ of minimal sporulation medium $\left(1 \mathrm{mM} \mathrm{MgCl}_{2} \times 6 \mathrm{H}_{2} \mathrm{O}, 1 \mathrm{mM} \mathrm{Ca}\left(\mathrm{NO}_{3}\right)_{2} \times 4 \mathrm{H}_{2} \mathrm{O}, 12.5 \mu \mathrm{M} \mathrm{ZnCl}_{2}, 2.5 \mu \mathrm{M} \mathrm{CuCl}_{2}\right.$, $2.5 \mu \mathrm{M} \mathrm{CoCl}_{2} \times 6 \mathrm{H}_{2} \mathrm{O}, 2.5 \mu \mathrm{M} \mathrm{Na}_{2} \mathrm{MoO}_{4} \times 2 \mathrm{H}_{2} \mathrm{O}, 5 \mu \mathrm{M}\left(\mathrm{NH}_{4}\right)_{2} \mathrm{SO}_{4}, 0.066 \mu \mathrm{M} \mathrm{MnSO}_{4} \times \mathrm{H}_{2} \mathrm{O}, 1 \mathrm{mM}$ $\mathrm{FeSO}_{4}$ and $1 \mathrm{M}$ maltose in bacto nutrient broth (Oxoid, Wesel, Northrhine-Westphalia, Germany); $\mathrm{pH}$ 7.6) were inoculated with $0.5 \%$ overnight culture (see Section 2.1 ) and incubated for three days at $32{ }^{\circ} \mathrm{C}$ and $200 \mathrm{rpm}$. Sporulation was monitored via bright-field microscopy. When $>80 \%$ spore content was reached, the cultures were centrifuged at $3500 \mathrm{rpm}$ and $4{ }^{\circ} \mathrm{C}$ for $10 \mathrm{~min}$, washed three times in pre-cooled spore washing buffer $\left(1 \mathrm{M} \mathrm{KH}_{2} \mathrm{PO}_{4}, 1 \mathrm{M} \mathrm{K}_{2} \mathrm{HPO}_{4}, \mathrm{pH} 7.4\right)$ and stored at $4{ }^{\circ} \mathrm{C}$.

\subsection{Germination}

For assessing germination of $B$. thuringiensis spores, media were inoculated to $\mathrm{OD}_{600}=1$. Two biological with three technical replicates for each strain were incubated in 96 -well plates at $37^{\circ} \mathrm{C}$ for one hour. As described before [14], $\mathrm{OD}_{620}$ was measured every three minutes in a Tecan photometer using Ridawin software. Germination is shown as the decrease of $\mathrm{OD}_{620}$ (in \%) per time. Germination 
was compared in CGY and cRPMI medium, as well as with and without prior heat activation for 10 min at $80^{\circ} \mathrm{C}$.

\subsection{Motility Assay}

To evaluate swimming behaviour of the $B$. thuringiensis strains, three replicates each were tested. For this, $1 \mu \mathrm{L}$ CGY overnight culture was injected into the centre of $53 \mathrm{~mm}$ diameter CGY agar plates containing $0.25 \%$ agar and incubated at $37^{\circ} \mathrm{C}$. Motility diameters were assessed after $24 \mathrm{~h}$.

\subsection{Enzyme Immunoassays (EIAs)}

Sandwich enzyme immunoassays for the detection of the enterotoxin components $\mathrm{NheB}$ and $\mathrm{Hbl}$ L2 were performed as described previously [33-35]. The following antibodies were used for detection: $5 \mu \mathrm{g} / \mathrm{mL}$ mAb 2B11/1E11-HRP 1:2000 (NheB) and $10 \mu \mathrm{g} / \mathrm{mL}$ mAb 1A12/1H9-HRP 1:1000 (Hbl L2). Titres are defined as the reciprocal of the highest dilutions resulting in an absorbance value of 21.0. Results were compared according to those titres, which were calculated from at least three replicates each.

\subsection{WST-1 Bioassay}

WST-1 bioassays were performed on CaCo-2 cells as described earlier [15]. Briefly, serial dilutions of the culture supernatants were applied to 96-well plates in RPMI 1640 medium (100 $\mu \mathrm{L} /$ well) before $2 \times 10^{4}$ three days old CaCo-2 cells/well $(100 \mu \mathrm{L})$ were added. After $24 \mathrm{~h}$ incubation at $37^{\circ} \mathrm{C}$ and $7 \%$ $\mathrm{CO}_{2}$, cell viability was determined by addition of the cell proliferation regent WST-1 (water soluble tetrazolium, Roche diagnostics, Penzberg, Bavaria, Germany). Increasing amounts of formazan were detected in a Tecan infinite F50 photometer at $450 \mathrm{~nm}$. Dose-response curves and thus, $50 \%$ lethal concentrations of at least two replicates were calculated with Magellan software and are shown as reciprocal titres.

\subsection{Haemolysis Assays}

CGY culture supernatants $(10 \mu \mathrm{L})$ were filled into stamp holes with five $\mathrm{mm}$ diameter on sheep blood agar plates. After five hours incubation at $32{ }^{\circ} \mathrm{C}$, haemolysis patterns were assessed.

\subsection{Disk Diffusion Assays}

To investigate antimicrobial effects of essential oils (EOs) on the B. thuringiensis isolates, disk diffusion assays were carried out according to Dussault et al. [36]. Cinnamon Chinese cassia and cinnamon OR (Cinnamomum cassia), citral (pure; 2,6-octadienal,3,7-dimethyl), oregano (Thymus capitatus Hoff.) and thyme (red; Thymus vulgaris and Thymus zygis L. var. gacilis Boissier) were provided by BSA Food Ingredients s.e.c./l.p. (Montréal, Canada). Winter savory (Satureja montana L.) was purchased from Alixir Essential Oils (Grondines, Canada). For the disk diffusion assays, CGY overnight cultures (see Section 2.1) were set to $\mathrm{OD}_{600}=0.5$ (approx. $10^{7} \mathrm{CFU} / \mathrm{mL}$ ) and $100 \mu \mathrm{L}$ were plated onto CGY agar. A sterile Whatmann paper disk (Ø $5 \mathrm{~mm})$ was placed in the middle of the plate and $1 \mu \mathrm{L}$ EO was dripped on it. After $24 \mathrm{~h}$ incubation at $37^{\circ} \mathrm{C}$, growth inhibition zones were measured. At least three replicates were prepared and examined.

\subsection{Antimicrobial Broth Dilution Assays}

EOs with antibacterial effects in the disk diffusion tests (see Section 2.11) were applied in antimicrobial broth dilution assays to determine minimal inhibitory as well as maximal tolerated concentrations according to Dussault et al. [36]. The EOs were set to a concentration of $2.5 \%$ (dissolved in sterile $\mathrm{H}_{2} \mathrm{O}$ with $5 \%$ Tween 80 ). The first column of a 96-well microtitre plates was filled with 167.7 $\mu \mathrm{L} \mathrm{CGY} \mathrm{medium} \mathrm{and} 33.3 \mu \mathrm{L}$ of the prepared EO solution. Columns two to 12 were filled with $100 \mu \mathrm{L}$ CGY and a two-fold dilution series was prepared. EO concentrations thus ranged from 0.42 to 
$0.00041 \%$. Column 12 was not filled with EOs and served as positive control. The B. thuringiensis CGY overnight cultures were set to $\mathrm{OD}_{600}=0.5$ (approx. $10^{7} \mathrm{CFU} / \mathrm{mL}$ ) and further diluted to approx. $10^{4} \mathrm{CFU} / \mathrm{mL}$. Rows A and $\mathrm{H}$ served as negative control, the remaining wells were filled with $10 \mu \mathrm{L}$ bacterial suspension. For the determination of the minimal inhibitory concentration (MIC) a total of $10^{6}$ $\mathrm{CFU} / \mathrm{mL}$ were used, $10^{3} \mathrm{CFU} / \mathrm{mL}$ to establish the maximal tolerated concentration (MTC). After $24 \mathrm{~h}$ incubation at $37^{\circ} \mathrm{C}, 10 \mu \mathrm{L}$ iodonitrotetrazolium chloride (Sigma-Aldrich/Merck KGaA, Darmstadt, Hesse, Germany) were added to each well. After further $60 \mathrm{~min}$ incubation at $37^{\circ} \mathrm{C}$, bacterial growth was measured at $\mathrm{OD}_{540}$ in a Tecan infinite F50 photometer. The MIC was calculated from the mean values of the lowest EO concentrations that prevented bacterial growth. The MTC was determined by the mean values of the maximal concentrations that allowed bacterial growth. The experiment was done twice with three technical replicates per strain.

\subsection{Statistical Analyses}

Data were statistically validated using the column statistics program of GraphPad Prism version 5.00 for Windows (GraphPad Software, San Diego, CA USA). Unpaired $t$-tests were applied with two-tailed $p$-values and $95 \%$ confidence interval. Significant differences were marked with * ( $p$-value $\leq 0.05)$. Furthermore, Spearman correlation tests were performed with two-tailed $p$-values and $95 \%$ confidence interval to determine correlations between data sets. Significant correlation was marked with * ( $p$-value $\leq 0.05)$.

\section{Results}

\subsection{Genetic Prerequisites of the Tested Strains}

In this study, 24 B. thuringiensis isolates of different origin (see Table 1) were characterized. For a rough overview on their phylogenetic relationship, the isolates were subjected to pan $C$ sequence typing, allocating them to panC type IV (Figure 1A). Distinct clusters within this group appeared (Figure 1B). In cluster a, MHI 2882 (B. thuringiensis ssp. israelensis isolated from larva) was found, as well as MHI 3241 and the older, barely documented isolate MHI 2878 (both B. thuringiensis ssp. tenebrionis), which might be identical. Cluster b comprised MHI 271, MHI 2873 (ATCC type strain) and MHI 3370. The reference strain B. cereus ATCC 14579 and MHI 2870 (B. thuringiensis ssp. entomocidus) belonged to cluster c. All further isolates clustered closer together. Cluster d comprised four biopesticidal strains and four food isolates, while in cluster e mainly soil and salad isolates appeared, with the exception of biopesticidal isolate MHI 3240. Interestingly, MHI 2872 and MHI 3189 (from ready-to-eat salad) in cluster d as well as MHI 2874 (B. thuringiensis ssp. kurstaki, isolated from soil) and MHI 3164 (also from ready-to-eat salad) in cluster e seemed to be identical.

Furthermore, all isolates were tested for the presence of cry genes via PCR with universal primers according to Ben-Dov et al. [24]. Thus, they could be verified as B. thuringiensis and additionally grouped in cry-type gene profiles (see Table 1 ). Twenty strains (83\%) were classified as cry1, while 13 of those (54\%) were also positive for cry2. Two strains (MHI 2878 and MHI 3241; B. thuringiensis ssp. tenebrionis) were allocated to the cry3-type and one strain (MHI 2882; Culicidae larva isolate) to cry4. MHI 3370, the ancrystalliferous derivate Bt $407 \mathrm{Cry}^{-}[37,38]$, was negative for all cry-types. Equally, all isolates were screened for the presence of (entero)toxin genes. All isolates harboured nhe A as well as $h b l C$, but were negative for ces as well as cytK1 (see Table 1). Twenty two strains (92\%) were tested positive for $c y t K 2$ and could thus be assigned to toxin profile A (nhe+, hbl+, cytK2+), while only two isolates (MHI 2878 and MHI 3241; B. thuringiensis ssp. tenebrionis) were cytK2 negative and thus, allocated to toxin profile $C(n h e+, h b l+)$ [39]. Interestingly, these were the two isolates assigned to the cry3-type. However, investigating a larger set of strains would be necessary to contextualize these observations. 

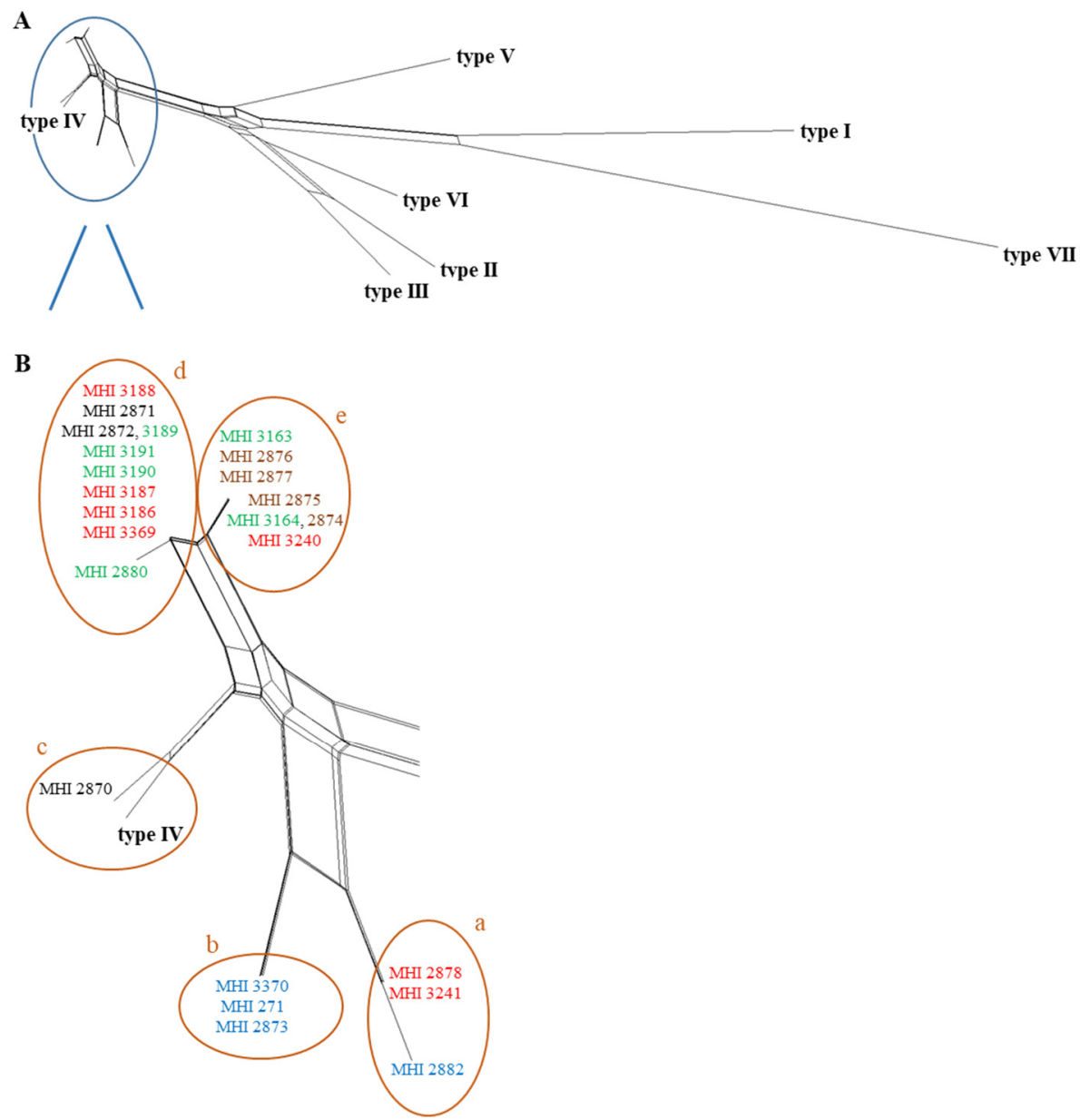

Figure 1. Phylogenetic relationship between the 24 tested B. thuringiensis strains, based on panC sequence analysis. Sequences were aligned with Clustal $\Omega$ [28] and further analysed using SplitsTree4 [29]. (A) Overview. (B) Enlargement of the B. thuringiensis isolates, which were all assigned to panC type IV. Within these, five distinct clusters (a-e) were identified. Blue: animal isolate, green: food, red: biopesticide, brown: soil, black: unknown origin.

\subsection{Strain-Specific Germination and Motility}

So far, all B. thuringiensis isolates in this study showed the genetic premises (presence of enterotoxin genes) to provoke the diarrhoeal type of food poisoning. Nevertheless, prerequisites for B. cereus enterotoxin production and cytotoxicity are also spore germination [14,40-43] and motility [14,44-46] in the host's intestine.

Within the B. thuringiensis strain set a high variability was detected, from maximal germination of $45 \%$ in CGY medium with heat activation to no germination. Furthermore, different germination patterns emerged (see Figure 2 and Table 2). Pattern A is characterized by minimal or no germination (MHI 2870 and MHI 2873). Strong germination in nutrient-rich medium with heat activation, but little germination in CRPMI medium was classified as pattern B (six food isolates, three biopesticidal strains and MHI 2882 isolated from larva). Pattern C germination seemed to be heat- as well as nutrient-dependent. This was detected for spores of biopesticidal strains as well as isolates of unknown origin. Pattern D comprised mostly soil isolates, which showed heat- and nutrient-independent germination. Spores with heat-dependent, but mostly nutrient-independent germination were summarized in pattern E. 

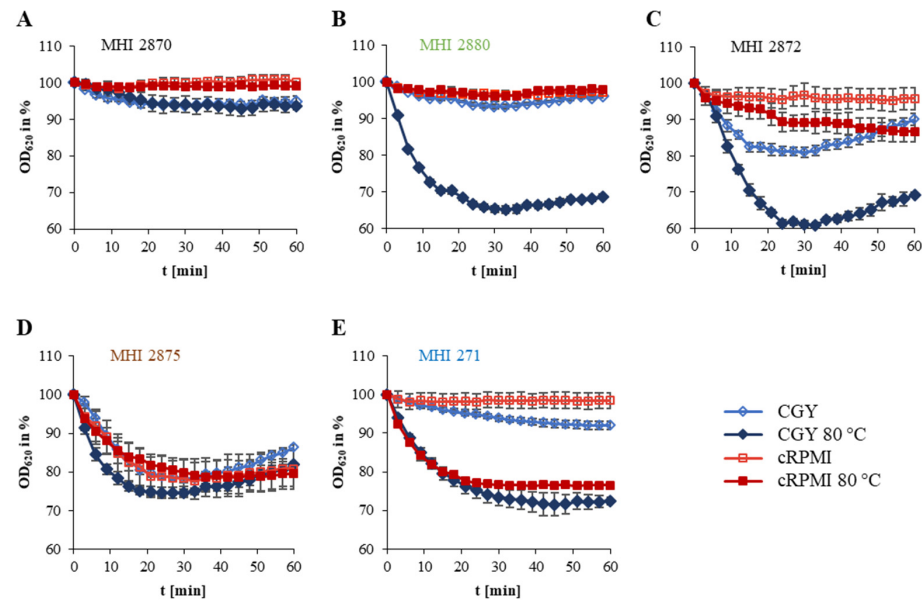

Figure 2. Germination of $B$. thuringiensis spores. Germination is depicted as the decrease of $\mathrm{OD}_{620}$ per unit of time. $\mathrm{OD}_{620}$ at time point 0 was set to $100 \%$. Due to different patterns, strains were assigned to five germination types. (A) Minimal to no germination. (B) Strong germination in nutrient-rich medium plus heat activation with little germination in cRPMI medium. (C) Heat- and nutrient-dependent germination. (D) Heat- and nutrient-independent germination. (E) Germination heat-dependent, but mostly nutrient-independent. Blue: animal isolate, green: food, red: biopesticide, brown: soil, black: unknown origin. CGY: casein-glucose-yeast full medium. CGY $80{ }^{\circ} \mathrm{C}$ : casein-glucose-yeast full medium with prior heat activation for $10 \mathrm{~min}$ at $80^{\circ} \mathrm{C}$. cRPMI: RPMI 1640 cell culture medium pre-incubated with CaCo-2 cells. cRPMI $80^{\circ} \mathrm{C}$ : RPMI 1640 cell culture medium pre-incubated with CaCo-2 cells and additional prior heat activation for $10 \mathrm{~min}$ at $80^{\circ} \mathrm{C}$.

Table 2. Germination of $B$. thuringiensis spores. Germination was measured as the decrease of $\mathrm{OD}_{620}$ per time. $\mathrm{OD}_{620}$ at time point 0 was set to $100 \%$. To compare germination rates of the 24 tested isolates, $\mathrm{OD}_{620}$ (in \%) after $15 \mathrm{~min}$ incubation is shown. Shown are means and standard deviations of at least two biological replicates, each comprising three technical replicates. Origin of the isolates: A: animal, F: food, P: pesticide, S: soil, U: unknown. Strains are sorted according to their germination patterns: A. Minimal to no germination. B. Strong germination in nutrient-rich medium plus heat activation with little germination in CRPMI medium. C. Heat- and nutrient-dependent germination. D. Heat- and nutrient-independent germination. E. Germination heat-dependent, but mostly nutrient-independent.

\begin{tabular}{|c|c|c|c|c|c|c|}
\hline \multirow{2}{*}{ Internal Number (MHI) } & \multirow{2}{*}{ Origin } & \multicolumn{4}{|c|}{ Germination $\left(\mathrm{OD}_{620}\right.$ in \%) after $15 \mathrm{~min}$} & \multirow{2}{*}{ Germination Pattern } \\
\hline & & CGY & $\mathrm{CGY} 80^{\circ} \mathrm{C}$ & cRPMI & cRPMI $80^{\circ} \mathrm{C}$ & \\
\hline 2870 & $\mathrm{U}$ & $94.2 \pm 0.6$ & $96.4 \pm 0.5$ & $97.8 \pm 1.3$ & $98.1 \pm 0.6$ & A \\
\hline 2873 & A & $96.6 \pm 0.8$ & $96.8 \pm 0.1$ & $98.5 \pm 1.3$ & $94.2 \pm 1.9$ & A \\
\hline 2880 & $\mathrm{~F}$ & $93.5 \pm 2.8$ & $71.4 \pm 1.4$ & $98.1 \pm 1.5$ & $98.9 \pm 1.4$ & B \\
\hline 2882 & A & $85.2 \pm 4.1$ & $78.0 \pm 1.0$ & $97.2 \pm 1.6$ & $96.4 \pm 2.8$ & B \\
\hline 3163 & $\mathrm{~F}$ & $94.8 \pm 0.6$ & $86.5 \pm 1.2$ & $98.8 \pm 0.7$ & $97.6 \pm 1.3$ & $\mathrm{~B}$ \\
\hline 3164 & $\mathrm{~F}$ & $94.1 \pm 0.3$ & $86.9 \pm 2.5$ & $98.6 \pm 1.7$ & $96.6 \pm 1.1$ & B \\
\hline 3186 & $\mathrm{P}$ & $98.5 \pm 0.3$ & $88.5 \pm 2.5$ & $99.8 \pm 0.3$ & $100.1 \pm 0.6$ & B \\
\hline 3187 & $\mathrm{P}$ & $98.9 \pm 0.9$ & $90.4 \pm 2.7$ & $99.4 \pm 0.7$ & $99.7 \pm 0.5$ & B \\
\hline 3188 & $\mathrm{P}$ & $96.0 \pm 0.4$ & $78.8 \pm 0.3$ & $98.4 \pm 0.5$ & $100.5 \pm 1.1$ & B \\
\hline 3189 & $\mathrm{~F}$ & $96.21 \pm 1.6$ & $88.2 \pm 2.3$ & $98.6 \pm 0.4$ & $100.6 \pm 0.8$ & B \\
\hline 3190 & $\mathrm{~F}$ & $98.4 \pm 0.6$ & $94.8 \pm 2.0$ & $99.1 \pm 0.9$ & $99.6 \pm 0.2$ & B \\
\hline 3191 & $\mathrm{~F}$ & $93.1 \pm 0.4$ & $77.2 \pm 0.7$ & $99.3 \pm 0.8$ & $99.2 \pm 0.1$ & B \\
\hline 2871 & $\mathrm{U}$ & $90.6 \pm 3.2$ & $82.4 \pm 2.1$ & $89.7 \pm 4.4$ & $91.3 \pm 3.0$ & $\mathrm{C}$ \\
\hline 2872 & $\mathrm{U}$ & $81.5 \pm 1.2$ & $72.6 \pm 2.9$ & $96.5 \pm 0.2$ & $93.4 \pm 0.4$ & $\mathrm{C}$ \\
\hline 3240 & $\mathrm{P}$ & $98.1 \pm 1.9$ & $79.2 \pm 1.3$ & $90.3 \pm 5.8$ & $93.0 \pm 1.9$ & $\mathrm{C}$ \\
\hline 3241 & $\mathrm{P}$ & $86.5 \pm 7.1$ & $75.6 \pm 10.9$ & $119.1 \pm 24.7$ & $85.2 \pm 11.1$ & $\mathrm{C}$ \\
\hline 3369 & $\mathrm{P}$ & $87.3 \pm 1.6$ & $75.2 \pm 2.7$ & $96.9 \pm 1.9$ & $95.0 \pm 1.6$ & $\mathrm{C}$ \\
\hline 2874 & S & $82.9 \pm 31.5$ & $62.0 \pm 4.1$ & $74.4 \pm 1.5$ & $81.7 \pm 1.5$ & $\mathrm{D}$ \\
\hline 2875 & S & $78.8 \pm 6.2$ & $74.8 \pm 1.9$ & $83.9 \pm 2.0$ & $82.7 \pm 1.8$ & $\mathrm{D}$ \\
\hline 2876 & $\mathrm{~S}$ & $87.1 \pm 1.9$ & $89.9 \pm 1.0$ & $90.1 \pm 4.9$ & $89.1 \pm 0.4$ & $\mathrm{D}$ \\
\hline 2877 & $S$ & $81.3 \pm 7.8$ & $75.6 \pm 9.6$ & $91.3 \pm 2.2$ & $93.5 \pm 1.4$ & $\mathrm{D}$ \\
\hline 3370 & A & $71.9 \pm 6.8$ & $64.5 \pm 8.2$ & $78.6 \pm 9.1$ & $78.2 \pm 9.5$ & $\mathrm{D}$ \\
\hline 271 & A & $95.2 \pm 1.3$ & $81.9 \pm 3.3$ & $97.7 \pm 0.6$ & $80.2 \pm 0.1$ & $\mathrm{E}$ \\
\hline 2878 & $\mathrm{P}$ & $96.1 \pm 1.8$ & $88.8 \pm 2.2$ & $96.4 \pm 2.0$ & $92.3 \pm 2.1$ & $\mathrm{E}$ \\
\hline
\end{tabular}


Beyond germination, the swimming ability of the isolates was investigated using CGY plates with $0.25 \%$ agar. With the exception of insect isolates MHI 2873 and MHI 2882, and biopesticide isolate MHI 3241, all strains were able to actively move after $24 \mathrm{~h}$ incubation at $37^{\circ} \mathrm{C}$, while $\mathrm{MHI}$ 2870, as well as the salad and biopesticide isolates MHI 3186, MHI 3187, MHI 3188, MHI 3189 and MHI 3190 showed maximal diameters (Figure 3). Generally, various strains-including isolates from biopesticides-were able to germinate in low-nutrient cRMPI medium and also to actively move; hence, further prerequisites for the onset of the disease are given.
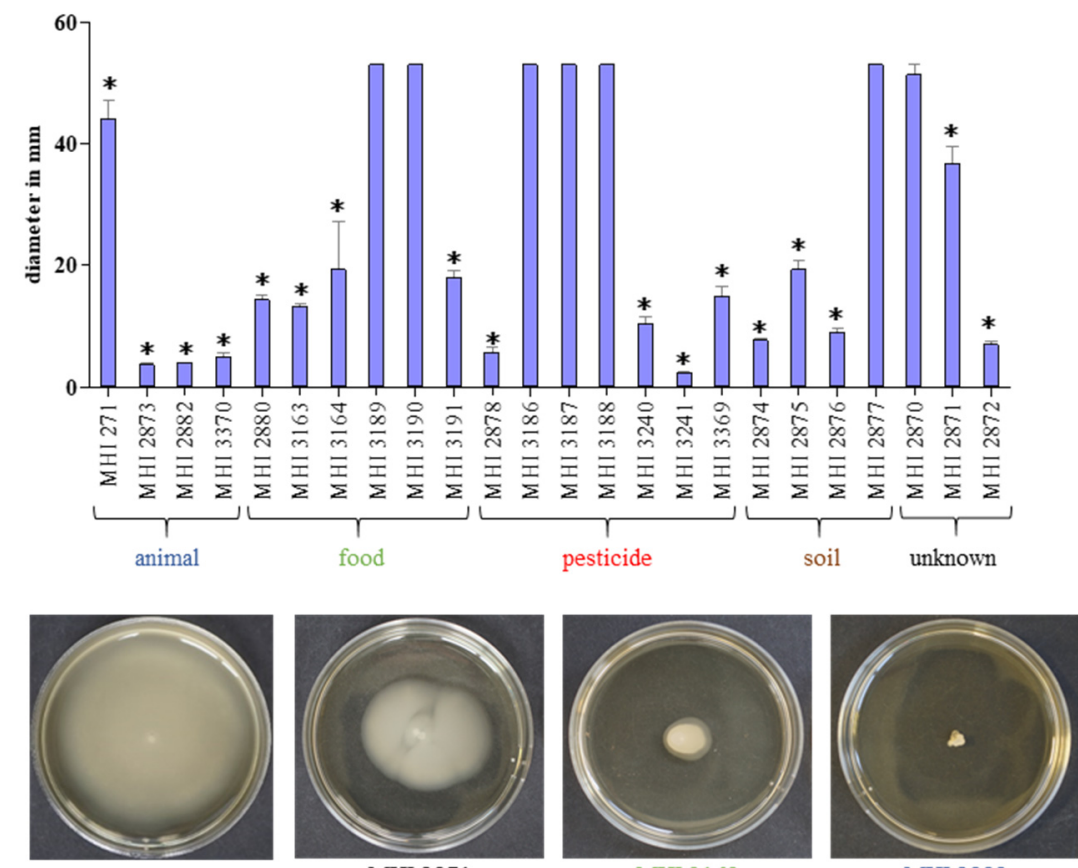

Figure 3. Motility of the $B$. thuringiensis isolates. The $1 \mu \mathrm{L}$ overnight culture was injected into the centre of CGY plates with $0.25 \%$ agar. Swimming diameters were measured after $24 \mathrm{~h}$ incubation at $37^{\circ} \mathrm{C}$. *: Significant difference compared to full-plate expansion ( $p$-value $\leq 0.05$; unpaired $t$-test, $95 \%$ confidence interval). Blue: animal isolate, green: food, red: biopesticide, brown: soil, black: unknown origin.

\subsection{Growth under Simulated Intestinal Conditions and Production of Enterotoxins}

The crucial step for B. cereus-associated food infections is growth and enterotoxin production of the bacteria in the human intestine. Representatively, reciprocal titres of toxin components NheB and $\mathrm{Hbl} \mathrm{L2}$ were determined in culture supernatants after six hours of growth. All B. thuringiensis isolates tested in this study were able to grow under simulated intestinal conditions (cRPMI medium, $37^{\circ} \mathrm{C}$, $7 \% \mathrm{CO}_{2}$ ) and to secrete significant amounts of NheB (Figure 4A,B). Applying a classification scheme developed for B. cereus (high NheB production: titres >2000; medium: 1000-2000; low: <1000; [15]), a uniform distribution of high, medium and low toxin producing strains was observed (see Table 1 and Figure 4B). Under these terms, eight strains (mainly biopesticide and salad isolates) showed NheB titres below 1000 (Figure 4B), but conclusions should be drawn carefully, as this is still sufficient to cause significant damage to $\mathrm{CaCo}-2$ cells (see Section 3.4). Additionally, NheB titres were determined after six hours growth in CGY medium, as this is applied in routine diagnostics of B. cereus [39]. Due to accelerated growth, titres were enhanced in CGY medium compared to cRPMI. Furthermore, all isolates secreted significant amounts of $\mathrm{Hbl} \mathrm{L2}$ under both conditions, similar to B. cereus [15,39], with the exception of Culicidae larva isolate MHI 2882 (Figure 4C). 
A
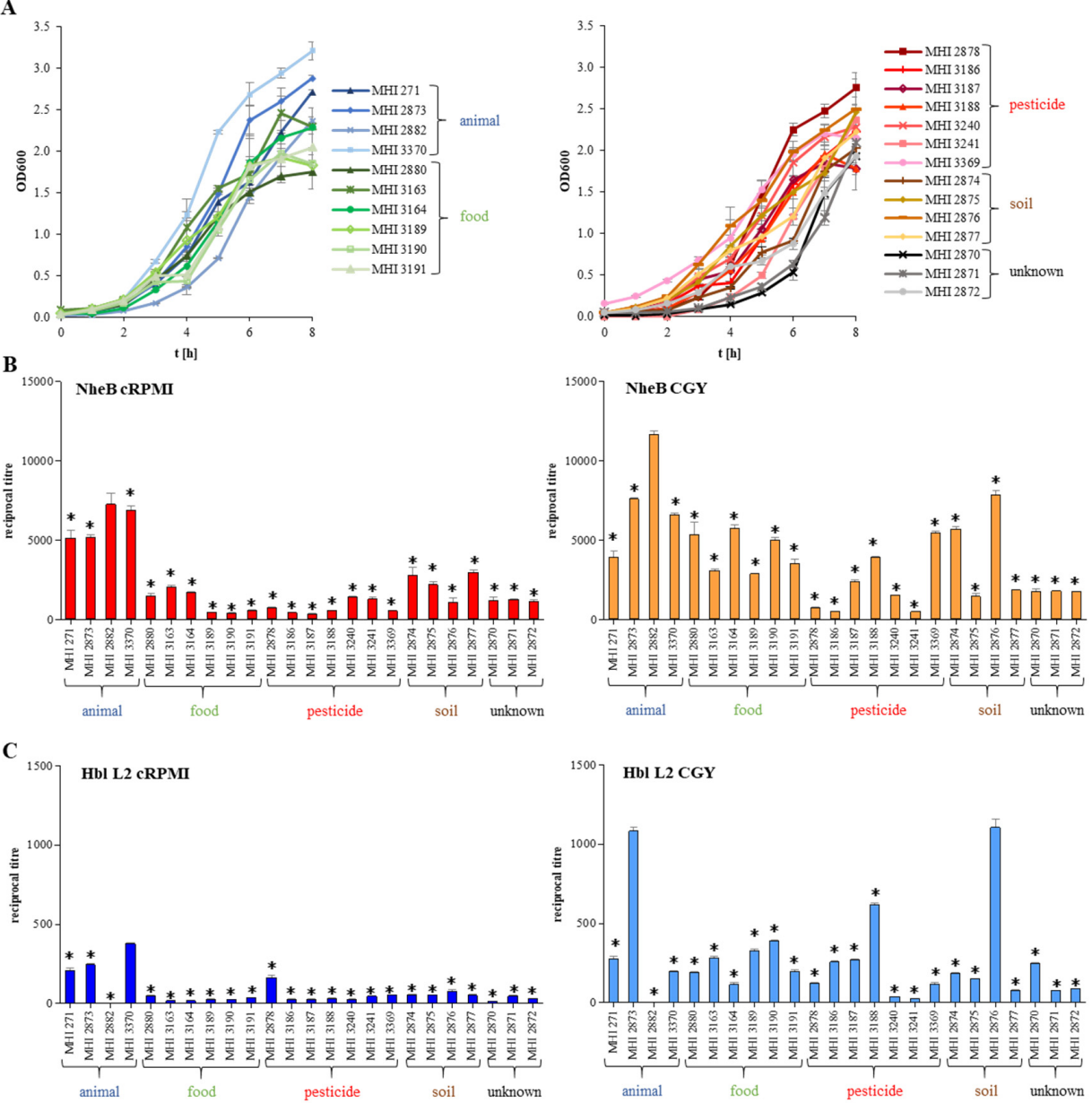

Figure 4. Growth and enterotoxin production of the B. thuringiensis strains. (A) Growth under simulated intestinal conditions (RPMI 1640 medium treated with $\mathrm{CaCo}-2$ cells, $37{ }^{\circ} \mathrm{C}, 7 \% \mathrm{CO}_{2}$ ). (B) NheB production after six hours growth under simulated intestinal conditions (cRPMI, red). Reciprocal NheB titres after six hours growth in CGY medium (nutrient-rich, aerobic conditions) are shown for comparison (orange). (C) Hbl L2 production after six hours growth under simulated intestinal conditions (cRPMI, dark blue). Reciprocal Hbl L2 titres after six hours growth in CGY medium (nutrient-rich, aerobic conditions) are shown for comparison (light blue). *: Significant difference compared to the isolate with highest toxin production ( $p$-value $\leq 0.05$; unpaired $t$-test, $95 \%$ confidence interval). Blue: animal isolate, green: food, red: biopesticide, brown: soil, black: unknown origin.

\subsection{Exhibition of Cytotoxic and Haemolytic Activity}

Beyond toxin production, all tested B. thuringiensis isolates grown under simulated intestinal conditions showed cytotoxic activity towards the human colon adenocarcinoma cell line $\mathrm{CaCo}-2$ (Figure 5A). According to a prior classification of B. cereus strains [15], 14 of the tested B. thuringiensis isolates were classified as highly (titres $>100$ ) and eight isolates as medium (titres from 50 to 100) toxic (see Table 1). Only two strains exhibited low cytotoxicity (titres $<50$ ), which were MHI 2870 and biopesticide isolate MHI 3241. Similar to toxin production (see Section 3.3), cytotoxicity titres where accordingly enhanced when the strains were grown in CGY medium (Figure 5A). Data from WST-1 bioassays were supported by haemolysis (Figure 5B). Only strain MHI 3241 exhibited no haemolytic activity on sheep blood agar. Extension of the haemolytic zone varied strain-specifically, with isolates MHI 271, MHI 2873 and MHI 3370 showing the discontinuous haemolysis zone phenomenon [13,47,48]. Furthermore, data obtained from EIAs and WST-1 bioassays were statistically analysed. Spearman correlation tests revealed that $\mathrm{NheB}, \mathrm{Hbl} \mathrm{L} 2$ and cytotoxicity titres of all tested $\mathrm{B}$. thuringiensis isolates generally tended to increase together, but weakly and in a non-significant manner (Table 3A). 
A

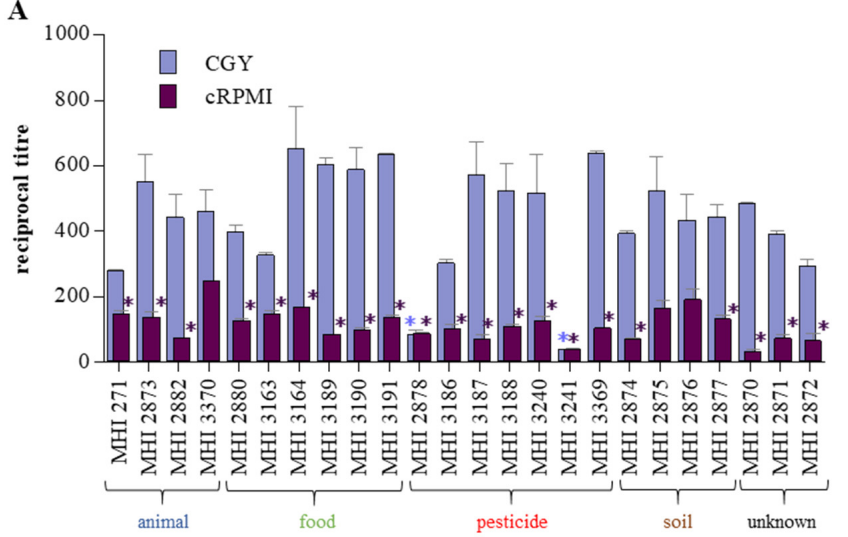

B

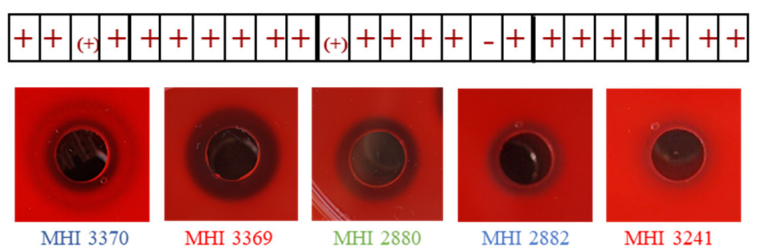

Figure 5. Cytotoxic activity of the 24 tested B. thuringiensis isolates. A. Results of WST-1 bioassays on CaCo-2 cells. Reciprocal titres for $50 \%$ lethal doses are shown. *: Significant difference compared to the isolate with highest cytotoxicity ( $p$-value $\leq 0.05$; unpaired $t$-test, $95 \%$ confidence interval). B. Haemolytic activity of the 24 isolates obtained after five hours incubation on sheep blood agar plates. +: Haemolysis clearly detectable. -: Haemolysis not detectable. (+): Weak haemolysis. Further, examples of five different haemolysis patterns are shown. Blue: animal isolate, green: food, red: biopesticide, brown: soil, black: unknown origin.

Table 3. Results of Spearman correlation tests. Correlation between reciprocal titres from EIAs and cytotoxicity tests (A), as well as correlation between MICs and MTCs of EOs (B) was determined for the 24 tested B. thuringiensis isolates. Pairs with positive correlation coefficients are shown, which tended to increase together. R: correlation coefficient. *: significant correlation ( $p$-value $\leq 0.05)$. ns: not significant.

\begin{tabular}{|c|c|c|c|}
\hline A & WST-1 CGY & & NheB CGY \\
\hline NheB CGY & $\mathrm{R}=0.37$ (ns) & NheB cRPMI & $\mathrm{R}=0.35$ (ns) \\
\hline \multirow[t]{2}{*}{$\mathrm{Hbl}$ L2 CGY } & $\mathrm{R}=0.237(\mathrm{~ns})$ & $\mathrm{Hbl}$ L2 CGY & $\mathrm{R}=0.297(\mathrm{~ns})$ \\
\hline & WST-1 cRPMI & & NheB cRPMI \\
\hline \multirow{3}{*}{$\begin{array}{l}\text { NheB cRPMI } \\
\text { Hbl L2 cRPMI }\end{array}$} & $\mathrm{R}=0.381$ (ns) & Hbl L2 cRPMI & $\mathrm{R}=0.283$ (ns) \\
\hline & $\mathrm{R}=0.375(\mathrm{~ns})$ & & \\
\hline & WST-1 CGY & & Hbl L2 CGY \\
\hline WST-1 cRPMI & $\mathrm{R}=0.237$ (ns) & $\mathrm{Hbl}$ L2 cRPMI & $\mathrm{R}=0.13(\mathrm{~ns})$ \\
\hline B & MIC Citral & & MIC Oregano \\
\hline \multirow[t]{2}{*}{ MTC Citral } & $\mathrm{R}=0.35$ (ns) & MTC Oregano & $\mathrm{R}=0.65\left(^{*}\right)$ \\
\hline & MIC Cassia & & MIC Winter s. \\
\hline \multirow[t]{3}{*}{ MIC Citral } & $\mathrm{R}=0.126(\mathrm{~ns})$ & MIC Citral & $\mathrm{R}=0.322(\mathrm{~ns})$ \\
\hline & & MIC Oregano & $\mathrm{R}=0.446\left(^{*}\right)$ \\
\hline & MTC Cassia & & MTC Winter s. \\
\hline MTC Oregano & $\mathrm{R}=0.285$ (ns) & MTC Oregano & $\mathrm{R}=0.16(\mathrm{~ns})$ \\
\hline
\end{tabular}




\subsection{Growth Inhibition by Essential Oils (EOs)}

Nearly all B. thuringiensis isolates tested in this study secreted sufficient amounts of enterotoxins under simulated intestinal conditions to harm human colon cells in a B. cereus-like magnitude. Thus, the antimicrobial activity of essential oils (EOs) was assessed as a preventive measure against putatively enteropathogenic $B$. thuringiensis. Initially, inhibition zones in disk diffusion assays were investigated. Except thyme, each EO was able to inhibit growth of all tested B. thuringiensis strains (Figure 6A and Figure S1). Susceptibility of all isolates to cinnamon OR was similar (inhibition zone approx. $11 \mathrm{~mm}$ ), with the exception of highly sensitive MHI 3241 (22 mm). For the other EOs, especially oregano, winter savory and citral, higher strain-specific variations were detected (Figure 6A and Figure S1).

$\mathbf{A}$
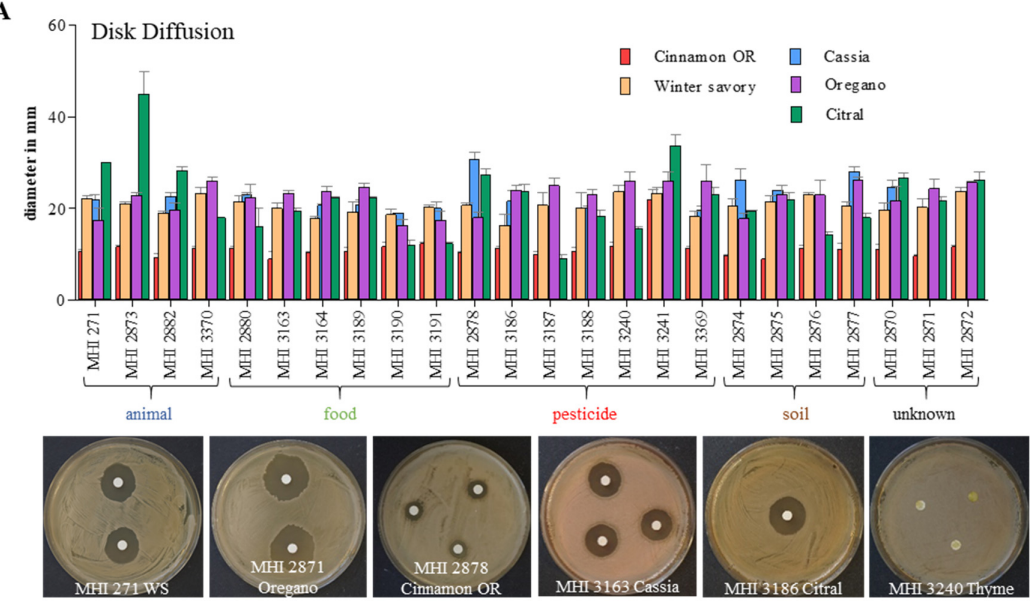

B

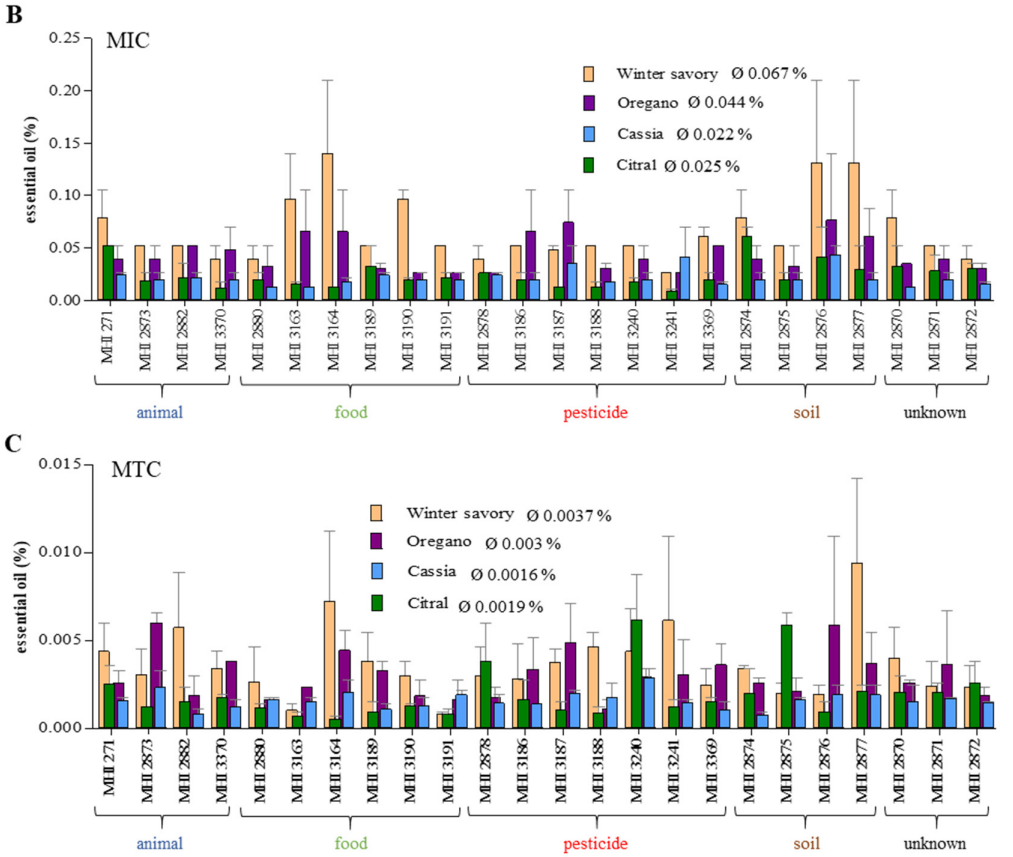

Figure 6. Antimicrobial activity of essential oils (EOs). (A) Disk diffusion assay. Approx. $10^{7} \mathrm{CFU} / \mathrm{mL}$ were plated onto CGY agar, a sterile paper disk was placed in the middle of the plate and $1 \mu \mathrm{L}$ EO was dripped on it. Growth inhibition zones were measured after $24 \mathrm{~h}$ incubation at $37^{\circ} \mathrm{C}$. (B) The minimal inhibitory concentrations (MICs) were determined in antimicrobial broth dilution assays using $10^{6} \mathrm{CFU} / \mathrm{mL}$. Ø: Average MIC value for all strains. (C) The maximal tolerated concentrations (MTCs) were determined in antimicrobial broth dilution assays using $10^{3} \mathrm{CFU} / \mathrm{mL}$. Ø: Average MTC value for all strains. For a better overview, separate diagrams including statistics are depicted in Figures S1-S3. Blue: animal isolate, green: food, red: biopesticide, brown: soil, black: unknown origin. 
Cinnamon Chinese cassia, citral, oregano and winter savory were then chosen to evaluate MIC and MTC values by performing antimicrobial broth dilution assays (Figure 6B,C, Figures S2 and S3). Average MICs were $0.067 \%$ for winter savory, $0.044 \%$ for oregano, $0.025 \%$ for citral and $0.022 \%$ for cinnamon Chinese cassia. Average MTCs were $0.0037 \%$ for winter savory, $0.003 \%$ for oregano, $0.0019 \%$ for citral and $0.0016 \%$ for cinnamon Chinese cassia. Thus, cinnamon Chinese cassia showed the highest antimicrobial activity towards the tested B. thuringiensis isolates, followed by citral, oregano and winter savory. Nonetheless, the previously observed highly strain-specific antimicrobial activity was further intensified (Figure 6B,C, Figures S2 and S3). MIC and MTC values of the strain set were also statistically analysed. Results of Spearman correlation tests are summarized in Table 3B. With the exception of oregano, MIC and MTC values did not significantly correlate. MIC values of citral and cinnamon Chinese cassia (not significantly), citral and winter savory (not significantly), and winter savory and oregano (significantly) tended to increase together. This was also observed for the MTC values of cinnamon Chinese cassia and oregano, and winter savory and oregano (not significant). Thus, despite some correlation, the great variability between the tested isolates became yet again obvious. Nevertheless, soil isolate MHI 2876, which showed highest resistance to all tested EOs, as well as biopesticide isolate MHI 3241 (B. thuringiensis ssp. tenebrionis), which was most susceptible to all tested EOs except cinnamon Chinese cassia, were particularly remarkable.

\section{Discussion}

Over 400 B. thuringiensis-based formulations have been registered, mostly consisting of insecticidal toxins and viable spores [22]. In Germany, there are currently 16 authorized plant protection products containing $B$. thuringiensis, including biopesticides 1,2 and 4 tested in the present study. The license for biopesticide 3 ended in 2019, its grace period ends in October 2020. B. thuringiensis concentrations of up to $540 \mathrm{~g} / \mathrm{kg}$ are used in these products [49]. The present study aimed to investigate the enteropathogenic potential of $B$. thuringiensis as well as its susceptibility to essential oils, with special attention being paid to differences between the single isolates from soil, animals, food and commercially available biopesticides. It is already known that B. thuringiensis, as member of the B. cereus group, harbours genes encoding enterotoxins, which were also detected in the present study (see Table 1). Remarkably, all strains harboured $h b l$, which is typically found in $40-70 \%$ of $B$. cereus group isolates under investigation $[26,50,51]$. One older study also described a significantly higher presence of $h b l C D A$ in B. thuringiensis than in B. cereus [52].

Furthermore, all isolates investigated in the present study were assigned to panC type IV. The authors of a previous study with similar results concluded that biopesticide strains can thus indeed be present in foods [23]. Meanwhile, B. cereus group isolates of panC type IV cannot only be found in soil, water or insects, but also in conjunction with diarrhoeal outbreaks [23,27,39]. Additionally, potentially toxigenic pesticidal strains were isolated from tomatoes, cucumbers and peppers [53]. B. thuringiensis strains from tomatoes and bell pepper matched MLST (Multilocus Sequence Typing) types of the biopesticidal strains B. thuringiensis ssp. kurstaki ABTS-351 and B. thuringiensis ssp. aizawai ABTS-1857 [54]. In another study, isolates from food and beverage samples were indistinguishable from B. thuringiensis ssp. kurstaki from commercial biopesticides [55]. B. thuringiensis ssp. kurstaki HD1 was detected in cabbage products for human consumption [56], and a biopesticidal strain was even isolated from faecal samples of greenhouse workers who were exposed to B. thuringiensis-based insecticides [57].

In order to assess the potential health risk originating from (biopesticidal) B. thuringiensis isolates in more detail, we additionally investigated germination and motility behaviour of the strain set, which are further crucial prerequisites for the onset of the diarrhoeal disease [14,40-46]. Although different germination patterns emerged, spores of most isolates were able to germinate, even in cRPMI medium with preceding heat treatment mimicking re-heating of stored foods and subsequent consumption. Although highly strain-specific, no significant differences between biopesticidal and other isolates were detected, which was also true for swimming motility (see Figures 2 and 3 and 
Table 2). A connection between motility and enterotoxin secretion in $B$. thuringiensis has already been made $[58,59]$.

Despite all important prerequisites, production of enterotoxins in the intestine is the most relevant factor for the manifestation of the diarrhoeal disease. Although enterotoxin production by B. thuringiensis isolated from different sources including biopesticides has been shown in previous studies, comparative cytotoxicity assays were rarely performed [23,60-63]. Moreover, to our knowledge, the present study is the first one to compare enterotoxin production and cytotoxicity of a set of B. thuringiensis isolates grown under simulated intestinal conditions. Generally, enterotoxin production as well as cytotoxic activity is highly variable within enteropathogenic B. cereus strains. The reasons for this are still not completely explored [39,64]. A similar variability in NheB and Hbl L2 production as well as cytotoxicity towards $\mathrm{CaCo}-2$ cells could be shown for the B. thuringiensis isolates investigated in the present study (see Figures 4 and 5). Nevertheless, applying a classification scheme established for enteropathogenic B. cereus grown under simulated intestinal conditions [15], the majority of our $B$. thuringiensis isolates had to be classified as medium or highly toxic, including biopesticide strains (see Table 1). Hence, despite high strain-specific variations, a considerable hazardous potential due to B. thuringiensis isolates from various origins is indisputable.

Due to these facts, the scientific opinion of the EFSA (European Foods Safety Authority) BIOHAZ Panel (2016) is entirely comprehensible. Clear discrimination between B. cereus and B. thuringiensis in routine food and clinical diagnostics is required as well as unequivocal identification of biopesticide strains by whole genome sequencing or additional, specific markers. For an improved risk assessment, further data on dose-response and characterization of $B$. thuringiensis are urgently needed, as well as field studies after application of the biopesticides to determine pre-harvest intervals [22]. On the other hand, the major advantage of $B$. thuringiensis-its high specificity towards single insect species-must not be neglected, which led to a significant reduction of the use of chemical insecticides $[1,65]$. Moreover, defenders of $B$. thuringiensis claim that the genotypes of biopesticidal strains have never been found in outbreaks, and that only environmental isolates, not biopesticidal strains, have been detected in high concentrations in foodstuffs [66]. However, particularly to prove this, more data on the biopesticide strains as well as reliable tools for their clear identification are necessary.

Until these data are available, the use of EOs can be an additional preventive strategy against putatively enteropathogenic $B$. thuringiensis. It has been shown that B. cereus is sensitive to EOs from nutmeg, mint, clove, oregano, cinnamon, sassafras, sage, thyme and rosemary [67-72], Satureja, Origanum and Thymus species [73,74], lemon, orange and bergamot [75], cumin, black pepper and black cumin [76,77], Daucus gracilis [78], as well as carvacrol [79-82] and many others. Nevertheless, most of these studies have been conducted with only one or few representative isolates, and a comparative study including $B$. cereus strains of different origin, toxin profile, cytotoxic activity etc. is missing. Studies on the sensitivity of $B$. thuringiensis are rarely found, and-due to the high variability inside the B. cereus group-conclusions cannot necessarily be drawn for B. thuringiensis. Only two earlier studies showed susceptibility of B. thuringiensis towards EOs of Thymus vulgaris [83] and Ferulago angulata [84]. In contrast to that, none of the tested strains in the present study was inhibited by thyme oil (Figure 6), which once more underlines the high variability of EO effects. Comparing average MIC values, we determined an antimicrobial activity of cinnamon Chinese cassia $>$ citral $>$ oregano $>$ winter savory, which largely corresponds with earlier studies on B. cereus [72]. However, as in all tests applied in this study, strain-specific differences must be considered.

\section{Conclusions}

Altogether, the present study stresses the enteropathogenic potential of B. thuringiensis, even of biopesticidal strains, which were generally indistinguishable from other isolates in the applied tests. Application of these pesticides might thus indeed constitute a hazard to human health. On the other hand, the use of $B$. thuringiensis in agriculture significantly reduced the application of chemical insecticides. We conclude that banning of $B$. thuringiensis biopesticides is not implementable due to 
its various advantages. Nevertheless, the applied strains have to be extremely well characterized (for instance by whole genome sequencing) and labelled to provide gapless information about their safety and to eliminate any human health hazard. At this, routine discrimination between B. cereus and B. thuringiensis is as important as controlled application of the biopesticides. Additionally, clear labelling of foods treated with $B$. thuringiensis can benefit consumers.

Until then, the use of essential oils as antimicrobials might diminish the risks by reducing the level of contamination, especially in times of increased antibiotic resistance and enhanced consumers' demand for natural antimicrobial agents. It can also be concluded from the present study that, whenever predicting the hazardous potential or using antimicrobials, the high variety within B. cereus group strains, even B. thuringiensis, must be taken into account, whether it be their ability to produce enterotoxins, their cytotoxic activity, or their resilience towards antimicrobials.

Supplementary Materials: The following are available online at http://www.mdpi.com/2304-8158/9/10/1484/s1, Table S1: Primers used in this study, Figure S1: Disk diffusion assay, Figure S2: Determination of minimal inhibitory concentrations (MICs) in antimicrobial broth dilution assays, Figure S3: Determination of maximal tolerated concentrations (MTCs) in antimicrobial broth dilution assays.

Author Contributions: Conceptualization, V.S., M.L., E.M. and N.J.; formal analysis, V.S. and N.J.; investigation, V.S., J.R. and N.J. writing-original draft, V.S. and N.J.; writing—review and editing, M.L. and E.M. All authors have read and agreed to the published version of the manuscript.

Funding: This research was funded by Deutsche Forschungsgemeinschaft, grant number JE 871/2-1.

Acknowledgments: The authors thank Nele Maxseiner for excellent technical assistance.

Conflicts of Interest: The authors declare no conflict of interest. The funders had no role in the design of the study; in the collection, analyses, or interpretation of data; in the writing of the manuscript, or in the decision to publish the results.

\section{References}

1. Chattopadhyay, P.; Banerjee, G. Recent advancement on chemical arsenal of Bt toxin and its application in pest management system in agricultural field. 3 Biotech 2018, 8, 201. [CrossRef] [PubMed]

2. Jouzani, G.S.; Valijanian, E.; Sharafi, R. Bacillus thuringiensis: A successful insecticide with new environmental features and tidings. Appl. Microbiol. Biotechnol. 2017, 101, 2691-2711. [CrossRef]

3. Schnepf, E.; Crickmore, N.; Van Rie, J.; Lereclus, D.; Baum, J.; Feitelson, J.; Zeigler, D.R.; Dean, D.H. Bacillus thuringiensis and its pesticidal crystal proteins. Microbiol. Mol. Biol. Rev. 1998, 62, 775-806. [CrossRef]

4. Xu, C.; Wang, B.C.; Yu, Z.; Sun, M. Structural insights into Bacillus thuringiensis Cry, Cyt and parasporin toxins. Toxins 2014, 6, 2732-2770. [CrossRef] [PubMed]

5. Donovan, W.P.; Engleman, J.T.; Donovan, J.C.; Baum, J.A.; Bunkers, G.J.; Chi, D.J.; Clinton, W.P.; English, L.; Heck, G.R.; Ilagan, O.M.; et al. Discovery and characterization of Sip1A: A novel secreted protein from Bacillus thuringiensis with activity against coleopteran larvae. Appl. Microbiol. Biotechnol. 2006, 72, 713-719. [CrossRef] [PubMed]

6. Hernández-Rodríguez, C.S.; Boets, A.; Van Rie, J.; Ferré, J. Screening and identification of vip genes in Bacillus thuringiensis strains. J. Appl. Microbiol. 2009, 107, 219-225. [CrossRef] [PubMed]

7. Höfte, H.; Whiteley, H.R. Insecticidal crystal proteins of Bacillus thuringiensis. Microbiol. Rev. 1989, 53, 242-255. [CrossRef] [PubMed]

8. Zhong, C.; Ellar, D.J.; Bishop, A.; Johnson, C.; Lin, S.; Hart, E.R. Characterization of a Bacillus thuringiensis delta-endotoxin which is toxic to insects in three orders. J. Invertebr. Pathol. 2000, 76, 131-139. [CrossRef] [PubMed]

9. Guinebretière, M.H.; Auger, S.; Galleron, N.; Contzen, M.; De Sarrau, B.; De Buyser, M.L.; Lamberet, G.; Fagerlund, A.; Granum, P.E.; Lereclus, D.; et al. Bacillus cytotoxicus sp. nov. is a novel thermotolerant species of the Bacillus cereus group occasionally associated with food poisoning. Int. J. Syst. Evol. Microbiol. 2013, 63, 31-40. [CrossRef] [PubMed] 
10. Jiménez, G.; Urdiain, M.; Cifuentes, A.; López-López, A.; Blanch, A.R.; Tamames, J.; Kämpfer, P.; Kolstø, A.B.; Ramón, D.; Martínez, J.F.; et al. Description of Bacillus toyonensis sp. nov., a novel species of the Bacillus cereus group, and pairwise genome comparisons of the species of the group by means of ANI calculations. Syst. Appl. Microbiol. 2013, 36, 383-391. [CrossRef]

11. Liu, Y.; Lai, Q.; Göker, M.; Meier-Kolthoff, J.P.; Wang, M.; Sun, Y.; Wang, L.; Shao, Z. Genomic insights into the taxonomic status of the Bacillus cereus group. Sci. Rep. 2015, 5, 14082. [CrossRef]

12. Stenfors Arnesen, L.P.; Fagerlund, A.; Granum, P.E. From soil to gut: Bacillus cereus and its food poisoning toxins. FEMS Microbiol. Rev. 2008, 32, 579-606. [CrossRef]

13. Beecher, D.J.; Schoeni, J.L.; Wong, A.C. Enterotoxic activity of hemolysin BL from Bacillus cereus. Infect. Immun. 1995, 63, 4423-4428. [CrossRef]

14. Jessberger, N.; Kranzler, M.; da Riol, C.; Schwenk, V.; Buchacher, T.; Dietrich, R.; Ehling-Schulz, M.; Märtlbauer, E. Assessing the toxic potential of enteropathogenic Bacillus cereus. Food Microbiol. 2019, 84, 103276. [CrossRef]

15. Jessberger, N.; Rademacher, C.; Krey, V.M.; Dietrich, R.; Mohr, A.K.; Böhm, M.E.; Scherer, S.; Ehling-Schulz, M.; Märtlbauer, E. Simulating intestinal growth conditions enhances toxin production of enteropathogenic Bacillus cereus. Front. Microbiol. 2017, 8, 627. [CrossRef]

16. Lund, T.; De Buyser, M.L.; Granum, P.E. A new cytotoxin from Bacillus cereus that may cause necrotic enteritis. Mol. Microbiol. 2000, 38, 254-261. [CrossRef]

17. Lund, T.; Granum, P.E. Characterisation of a non-haemolytic enterotoxin complex from Bacillus cereus isolated after a foodborne outbreak. FEMS Microbiol. Lett. 1996, 141, 151-156. [CrossRef]

18. Cho, S.H.; Kang, S.H.; Lee, Y.E.; Kim, S.J.; Yoo, Y.B.; Bak, Y.S.; Kim, J.B. Distribution of toxin genes and enterotoxins in Bacillus thuringiensis isolated from microbial insecticide products. J. Microbiol. Biotechnol. 2015, 25, 2043-2048. [CrossRef]

19. Kim, M.J.; Han, J.K.; Park, J.S.; Lee, J.S.; Lee, S.H.; Cho, J.I.; Kim, K.S. Various enterotoxin and other virulence factor genes widespread among Bacillus cereus and Bacillus thuringiensis strains. J. Microbiol. Biotechnol. 2015, 25, 872-879. [CrossRef]

20. Swiecicka, I.; Van der Auwera, G.A.; Mahillon, J. Hemolytic and nonhemolytic enterotoxin genes are broadly distributed among Bacillus thuringiensis isolated from wild mammals. Microb. Ecol. 2006, 52, 544-551. [CrossRef]

21. McIntyre, L.; Bernard, K.; Beniac, D.; Isaac-Renton, J.L.; Naseby, D.C. Identification of Bacillus cereus group species associated with food poisoning outbreaks in British Columbia, Canada. Appl. Environ. Microbiol. 2008, 74, 7451-7453. [CrossRef]

22. EFSA, European Foods Safety Authority, Panel on Biological Hazards. Risks for public health related to the presence of Bacillus cereus and other Bacillus spp. including Bacillus thuringiensis in foodstuffs. EFSA J. 2016, 14, 4524. [CrossRef]

23. Johler, S.; Kalbhenn, E.M.; Heini, N.; Brodmann, P.; Gautsch, S.; Bagcioglu, M.; Contzen, M.; Stephan, R.; Ehling-Schulz, M. Enterotoxin production of Bacillus thuringiensis isolates from biopesticides, foods, and outbreaks. Front. Microbiol. 2018, 9, 1915. [CrossRef]

24. Ben-Dov, E.; Zaritsky, A.; Dahan, E.; Barak, Z.; Sinai, R.; Manasherob, R.; Khamraev, A.; Troitskaya, E.; Dubitsky, A.; Berezina, N.; et al. Extended screening by PCR for seven cry-group genes from field-collected strains of Bacillus thuringiensis. Appl. Environ. Microbiol. 1997, 63, 4883-4890. [CrossRef]

25. Wehrle, E.; Moravek, M.; Dietrich, R.; Bürk, C.; Didier, A.; Märtlbauer, E. Comparison of multiplex PCR, enzyme immunoassay and cell culture methods for the detection of enterotoxinogenic Bacillus cereus. J. Microbiol. Methods 2009, 78, 265-270. [CrossRef]

26. Ehling-Schulz, M.; Guinebretiére, M.H.; Monthan, A.; Berge, O.; Fricker, M.; Svensson, B. Toxin gene profiling of enterotoxic and emetic Bacillus cereus. FEMS Microbiol. Lett. 2006, 260, 232-240. [CrossRef]

27. Guinebretiére, M.H.; Thompson, F.L.; Sorokin, A.; Normand, P.; Dawyndt, P.; Ehling-Schulz, M.; Svensson, B.; Sanchis, V.; Nguyen-The, C.; Heyndrickx, M.; et al. Ecological diversification in the Bacillus cereus Group. Environ. Microbiol. 2008, 10, 851-865. [CrossRef]

28. Sievers, F.; Wilm, A.; Dineen, D.; Gibson, T.J.; Karplus, K.; Li, W.; Lopez, R.; McWilliam, H.; Remmert, M.; Soding, J.; et al. Fast, scalable generation of high-quality protein multiple sequence alignments using Clustal Omega. Mol. Syst. Biol. 2011, 7, 539. [CrossRef] 
29. Huson, D.H.; Bryant, D. Application of phylogenetic networks in evolutionary studies. Mol. Biol. Evol. 2006, 23, 254-267. [CrossRef]

30. Miller, R.A.; Jian, J.; Beno, S.M.; Wiedmann, M.; Kovac, J. Intraclade variability in toxin production and cytotoxicity of Bacillus cereus group type strains and dairy-associated isolates. Appl. Environ. Microbiol. 2018, 84. [CrossRef]

31. Fricker, M.; Agren, J.; Segerman, B.; Knutsson, R.; Ehling-Schulz, M. Evaluation of Bacillus strains as model systems for the work on Bacillus anthracis spores. Int. J. Food Microbiol. 2011, 145, 129-136. [CrossRef] [PubMed]

32. da Riol, C.D.; Dietrich, R.; Märtlbauer, E.; Jessberger, N. Consumed foodstuffs have a crucial impact on the toxic activity of enteropathogenic Bacillus cereus. Front. Microbiol. 2018, 9, 1946. [CrossRef] [PubMed]

33. Dietrich, R.; Fella, C.; Strich, S.; Märtlbauer, E. Production and characterization of monoclonal antibodies against the hemolysin BL enterotoxin complex produced by Bacillus cereus. Appl. Environ. Microbiol. 1999, 65, 4470-4474. [CrossRef]

34. Dietrich, R.; Moravek, M.; Bürk, C.; Granum, P.E.; Märtlbauer, E. Production and characterization of antibodies against each of the three subunits of the Bacillus cereus nonhemolytic enterotoxin complex. Appl. Environ. Microbiol. 2005, 71, 8214-8220. [CrossRef] [PubMed]

35. Tausch, F.; Dietrich, R.; Schauer, K.; Janowski, R.; Niessing, D.; Märtlbauer, E.; Jessberger, N. Evidence for complex formation of the Bacillus cereus haemolysin BL components in solution. Toxins 2017, 9, 288. [CrossRef]

36. Dussault, D.; Vu, K.D.; Lacroix, M. In vitro evaluation of antimicrobial activities of various commercial essential oils, oleoresin and pure compounds against food pathogens and application in ham. Meat Sci. 2014, 96, 514-520. [CrossRef]

37. Lereclus, D.; Arantes, O.; Chaufaux, J.; Lecadet, M. Transformation and expression of a cloned delta-endotoxin gene in Bacillus thuringiensis. FEMS Microbiol. Lett. 1989, 51, 211-217. [CrossRef]

38. Sheppard, A.E.; Poehlein, A.; Rosenstiel, P.; Liesegang, H.; Schulenburg, H. Complete Genome Sequence of Bacillus thuringiensis Strain 407 Cry. Genome Announc. 2013, 1. [CrossRef]

39. Jessberger, N.; Krey, V.M.; Rademacher, C.; Böhm, M.E.; Mohr, A.K.; Ehling-Schulz, M.; Scherer, S.; Märtlbauer, E. From genome to toxicity: A combinatory approach highlights the complexity of enterotoxin production in Bacillus cereus. Front. Microbiol. 2015, 6, 560. [CrossRef]

40. Wijnands, L.M.; Dufrenne, J.B.; Zwietering, M.H.; van Leusden, F.M. Spores from mesophilic Bacillus cereus strains germinate better and grow faster in simulated gastro-intestinal conditions than spores from psychrotrophic strains. Int. J. Food Microbiol. 2006, 112, 120-128. [CrossRef]

41. Wijnands, L.M.; Dufrenne, J.B.; van Leusden, F.M.; Abee, T. Germination of Bacillus cereus spores is induced by germinants from differentiated Caco-2 Cells, a human cell line mimicking the epithelial cells of the small intestine. Appl. Environ. Microbiol. 2007, 73, 5052-5054. [CrossRef] [PubMed]

42. Hornstra, L.M.; van der Voort, M.; Wijnands, L.M.; Roubos-van den Hil, P.J.; Abee, T. Role of germinant receptors in Caco-2 cell-initiated germination of Bacillus cereus ATCC 14579 endospores. Appl. Environ. Microbiol. 2009, 75, 1201-1203. [CrossRef] [PubMed]

43. Jessberger, N.; Dietrich, R.; Mohr, A.K.; da Riol, C.; Märtlbauer, E. Porcine gastric mucin triggers toxin production of enteropathogenic Bacillus cereus. Infect. Immun. 2019, 87, e00765-18. [CrossRef]

44. Ghelardi, E.; Celandroni, F.; Salvetti, S.; Ceragioli, M.; Beecher, D.J.; Senesi, S.; Wong, A.C. Swarming behavior of and hemolysin BL secretion by Bacillus cereus. Appl. Environ. Microbiol. 2007, 73, 4089-4093. [CrossRef] [PubMed]

45. Mazzantini, D.; Celandroni, F.; Salvetti, S.; Gueye, S.A.; Lupetti, A.; Senesi, S.; Ghelardi, E. FlhF is required for swarming motility and full pathogenicity of Bacillus cereus. Front. Microbiol. 2016, 7, 1644. [CrossRef]

46. Salvetti, S.; Ghelardi, E.; Celandroni, F.; Ceragioli, M.; Giannessi, F.; Senesi, S. FlhF, a signal recognition particle-like GTPase, is involved in the regulation of flagellar arrangement, motility behaviour and protein secretion in Bacillus cereus. Microbiology 2007, 153, 2541-2552. [CrossRef]

47. Beecher, D.J.; Macmillan, J.D. Characterization of the components of hemolysin BL from Bacillus cereus. Infect. Immun. 1991, 59, 1778-1784. [CrossRef]

48. Beecher, D.J.; Wong, A.C. Tripartite hemolysin BL from Bacillus cereus. Hemolytic analysis of component interactions and a model for its characteristic paradoxical zone phenomenon. J. Biol. Chem. 1997, 272, 233-239. [CrossRef] 
49. BVL (Federal Office of Consumer Protection and Food Safety). List of Authorised Plant Protection Products in Germany with Information on Terminated Authorisations. Available online: www.bvl.bund.de (accessed on 12 October 2020).

50. Ankolekar, C.; Rahmati, T.; Labbe, R.G. Detection of toxigenic Bacillus cereus and Bacillus thuringiensis spores in U.S. rice. Int. J. Food Microbiol. 2009, 128, 460-466. [CrossRef]

51. Böhm, M.E.; Huptas, C.; Krey, V.M.; Scherer, S. Massive horizontal gene transfer, strictly vertical inheritance and ancient duplications differentially shape the evolution of Bacillus cereus enterotoxin operons $h b l, c y t K$ and nhe. BMC Evol. Biol. 2015, 15, 246. [CrossRef]

52. Ngamwongsatit, P.; Buasri, W.; Pianariyanon, P.; Pulsrikarn, C.; Ohba, M.; Assavanig, A.; Panbangred, W. Broad distribution of enterotoxin genes ( $h b l C D A$, nhe $A B C, c y t K$, and entFM) among Bacillus thuringiensis and Bacillus cereus as shown by novel primers. Int. J. Food Microbiol. 2008, 121, 352-356. [CrossRef] [PubMed]

53. Frederiksen, K.; Rosenquist, H.; Jorgensen, K.; Wilcks, A. Occurrence of natural Bacillus thuringiensis contaminants and residues of Bacillus thuringiensis-based insecticides on fresh fruits and vegetables. Appl. Environ. Microbiol. 2006, 72, 3435-3440. [CrossRef]

54. Frentzel, H.; Juraschek, K.; Pauly, N.; Kelner-Burgos, Y.; Wichmann-Schauer, H. Indications of biopesticidal Bacillus thuringiensis strains in bell pepper and tomato. Int. J. Food Microbiol. 2020, 321, 108542. [CrossRef]

55. Zhou, G.; Yan, J.; Dasheng, Z.; Zhou, X.; Yuan, Z. The residual occurrences of Bacillus thuringiensis biopesticides in food and beverages. Int. J. Food Microbiol. 2008, 127, 68-72. [CrossRef]

56. Hendriksen, N.B.; Hansen, B.M. Detection of Bacillus thuringiensis kurstaki HD1 on cabbage for human consumption. FEMS Microbiol. Lett. 2006, 257, 106-111. [CrossRef] [PubMed]

57. Jensen, G.B.; Larsen, P.; Jacobsen, B.L.; Madsen, B.; Wilcks, A.; Smidt, L.; Andrup, L. Isolation and characterization of Bacillus cereus-like bacteria from faecal samples from greenhouse workers who are using Bacillus thuringiensis-based insecticides. Int. Arch. Occup. Environ. Health 2002, 75, 191-196. [CrossRef] [PubMed]

58. Ghelardi, E.; Celandroni, F.; Salvetti, S.; Beecher, D.J.; Gominet, M.; Lereclus, D.; Wong, A.C.; Senesi, S. Requirement of $f h A$ for swarming differentiation, flagellin export, and secretion of virulence-associated proteins in Bacillus thuringiensis. J. Bacteriol. 2002, 184, 6424-6433. [CrossRef]

59. Bouillaut, L.; Ramarao, N.; Buisson, C.; Gilois, N.; Gohar, M.; Lereclus, D.; Nielsen-Leroux, C. FlhA influences Bacillus thuringiensis PlcR-regulated gene transcription, protein production, and virulence. Appl. Environ. Microbiol. 2005, 71, 8903-8910. [CrossRef]

60. Gaviria Rivera, A.M.; Granum, P.E.; Priest, F.G. Common occurrence of enterotoxin genes and enterotoxicity in Bacillus thuringiensis. FEMS Microbiol. Lett. 2000, 190, 151-155. [CrossRef] [PubMed]

61. Yang, C.Y.; Pang, J.C.; Kao, S.S.; Tsen, H.Y. Enterotoxigenicity and cytotoxicity of Bacillus thuringiensis strains and development of a process for Cry1Ac production. J. Agric. Food Chem. 2003, 51, 100-105. [CrossRef] [PubMed]

62. Damgaard, P.H. Diarrhoeal enterotoxin production by strains of Bacillus thuringiensis isolated from commercial Bacillus thuringiensis-based insecticides. FEMS Immunol. Med. Microbiol. 1995, 12, 245-250. [CrossRef] [PubMed]

63. Damgaard, P.H.; Larsen, H.D.; Hansen, B.M.; Bresciani, J.; Jørgensen, K. Enterotoxin-producing strains of Bacillus thuringiensis isolated from food. Lett. Appl. Microbiol. 1996, 23, 146-150. [CrossRef] [PubMed]

64. Böhm, M.E.; Krey, V.M.; Jessberger, N.; Frenzel, E.; Scherer, S. Comparative bioinformatics and experimental analysis of the intergenic regulatory regions of Bacillus cereus $h b l$ and nhe enterotoxin operons and the impact of CodY on virulence heterogeneity. Front. Microbiol. 2016, 7, 768. [CrossRef]

65. Bravo, A.; Gomez, I.; Porta, H.; Garcia-Gomez, B.I.; Rodriguez-Almazan, C.; Pardo, L.; Soberon, M. Evolution of Bacillus thuringiensis Cry toxins insecticidal activity. Microb. Biotechnol. 2013, 6, 17-26. [CrossRef] [PubMed]

66. Raymond, B.; Federici, B.A. In defense of Bacillus thuringiensis, the safest and most successful microbial insecticide available to humanity-A response to EFSA. FEMS Microbiol. Ecol. 2017, 93. [CrossRef] [PubMed]

67. Unlu, M.; Ergene, E.; Unlu, G.V.; Zeytinoglu, H.S.; Vural, N. Composition, antimicrobial activity and in vitro cytotoxicity of essential oil from Cinnamomum zeylanicum Blume (Lauraceae). Food Chem. Toxicol. 2010, 48, 3274-3280. [CrossRef]

68. Valero, M.; Giner, M.J. Effects of antimicrobial components of essential oils on growth of Bacillus cereus INRA L2104 in and the sensory qualities of carrot broth. Int. J. Food Microbiol. 2006, 106, 90-94. [CrossRef] 
69. Valero, M.; Salmeron, M.C. Antibacterial activity of 11 essential oils against Bacillus cereus in tyndallized carrot broth. Int. J. Food Microbiol. 2003, 85, 73-81. [CrossRef]

70. Ghosh, I.N.; Patil, S.D.; Sharma, T.K.; Srivastava, S.K.; Pathania, R.; Navani, N.K. Synergistic action of cinnamaldehyde with silver nanoparticles against spore-forming bacteria: A case for judicious use of silver nanoparticles for antibacterial applications. Int. J. Nanomedicine 2013, 8, 4721-4731. [CrossRef]

71. Kwon, J.A.; Yu, C.B.; Park, H.D. Bacteriocidal effects and inhibition of cell separation of cinnamic aldehyde on Bacillus cereus. Lett. Appl. Microbiol. 2003, 37, 61-65. [CrossRef]

72. Friedman, M.; Buick, R.; Elliott, C.T. Antibacterial activities of naturally occurring compounds against antibiotic-resistant Bacillus cereus vegetative cells and spores, Escherichia coli, and Staphylococcus aureus. J. Food Prot. 2004, 67, 1774-1778. [CrossRef]

73. Chorianopoulos, N.; Kalpoutzakis, E.; Aligiannis, N.; Mitaku, S.; Nychas, G.J.; Haroutounian, S.A. Essential oils of Satureja, Origanum, and Thymus species: Chemical composition and antibacterial activities against foodborne pathogens. J. Agric. Food Chem. 2004, 52, 8261-8267. [CrossRef]

74. Oke, F.; Aslim, B.; Ozturk, S.; Altundag, S. Essential oil composition, antimicrobial and antioxidant anctivities of Satureja cuneifolia Ten. Food Chem. 2009, 112, 874-879. [CrossRef]

75. Fisher, K.; Phillips, C.A. The effect of lemon, orange and bergamot essential oils and their components on the survival of Campylobacter jejuni, Escherichia coli O157, Listeria monocytogenes, Bacillus cereus and Staphylococcus aureus in vitro and in food systems. J. Appl. Microbiol. 2006, 101, 1232-1240. [CrossRef]

76. Singh, G.; Marimuthu, P.; Murali, H.S.; Bawa, A.S. Antioxidative and antibacterial potentials of essential oils and extracts isolated from various spice materials. J. Food Saf. 2005, 25, 130-145. [CrossRef]

77. Singh, S.; Das, S.S.; Singh, G.; Schuff, C.; de Lampasona, M.P.; Catalan, C.A. Composition, in vitro antioxidant and antimicrobial activities of essential oil and oleoresins obtained from black cumin seeds (Nigella sativa L.). Biomed. Res. Int. 2014, 2014, 918209. [CrossRef]

78. El Kolli, M.; Laouer, H.; El Kolli, H.; Akkal, S.; Sahli, F. Chemical analysis, antimicrobial and anti-oxidative properties of Daucus gracilis essential oil and its mechanism of action. Asian Pac. J. Trop. Biomed. 2016, 6, 8-15. [CrossRef]

79. Ultee, A.; Bennik, M.H.; Moezelaar, R. The phenolic hydroxyl group of carvacrol is essential for action against the food-borne pathogen Bacillus cereus. Appl. Environ. Microbiol. 2002, 68, 1561-1568. [CrossRef]

80. Ultee, A.; Gorris, L.G.; Smid, E.J. Bactericidal activity of carvacrol towards the food-borne pathogen Bacillus cereus. J. Appl. Microbiol. 1998, 85, 211-218. [CrossRef]

81. Ultee, A.; Kets, E.P.; Alberda, M.; Hoekstra, F.A.; Smid, E.J. Adaptation of the food-borne pathogen Bacillus cereus to carvacrol. Arch. Microbiol. 2000, 174, 233-238. [CrossRef]

82. Ultee, A.; Smid, E.J. Influence of carvacrol on growth and toxin production by Bacillus cereus. Int. J. Food Microbiol. 2001, 64, 373-378. [CrossRef]

83. Marino, M.; Bersani, C.; Comi, G. Antimicrobial activity of the essential oils of Thymus vulgaris L. measured using a bioimpedometric method. J. Food Prot. 1999, 62, 1017-1023. [CrossRef]

84. Moghaddam, M.; Mehdizadeh, L.; Mirzaei Najafgholi, H.; Ghasemi Pirbalouti, A. Chemical composition, antibacterial and antifungal activities of seed essential oil of Ferulago angulata. Int. J. Food Prop. 2018, 21, 158-170. [CrossRef]

Publisher's Note: MDPI stays neutral with regard to jurisdictional claims in published maps and institutional affiliations.

(C) 2020 by the authors. Licensee MDPI, Basel, Switzerland. This article is an open access article distributed under the terms and conditions of the Creative Commons Attribution (CC BY) license (http://creativecommons.org/licenses/by/4.0/). 